\title{
Protective effects of bark ethanolic extract from Spondias dulcis Forst F. against DNA damage induced by benzo[a]pyrene and cyclophosphamide
}

\author{
Caroline de S. Araujo ${ }^{1 *}$, Lorrane D. Brito ${ }^{1 *}$, Marina O. Tarifa ${ }^{2}$, Nayara J. Farah da Silva ${ }^{2}$, Karoline S. \\ Rodrigues $^{3}$, Dalita G. S. M. Cavalcante ${ }^{4}$, Andressa S. Gomes ${ }^{4}$, Marcos A. Zocoler ${ }^{3}$, Eidi Yoshihara ${ }^{5}$, Marjori \\ L. Camparoto ${ }^{2}$, Aldo E. Job ${ }^{4}$ and Leandra E. Kerche ${ }^{1,2}$ iD \\ ${ }^{1}$ Faculdade de Artes, Ciências, Letras e Educação, Universidade do Oeste Paulista, Presidente Prudente, \\ SP, Brazil. \\ ${ }^{2}$ Faculdade de Medicina, Universidade do Oeste Paulista, Presidente Prudente, SP, Brazil. \\ ${ }^{3}$ Faculdade de Farmácia, Universidade do Oeste Paulista, Presidente Prudente, SP, Brazil. \\ ${ }^{4}$ Departmento de Física, Química e Biologia, Universidade Estadual Paulista "Júlio de Mesquita Filho", \\ Presidente Prudente, SP, Brazil. \\ ${ }^{5}$ Agência Paulista de Tecnologia dos Agronegócios (APTA), Presidente Prudente, SP, Brazil.
}

\begin{abstract}
This study evaluated the genotoxicity, mutagenicity, antigenotoxicity, and antimutagenicity effects on biochemical parameters of oxidative stress of the Spondias dulcis bark ethanolic extract on mice. The extract was evaluated in the doses of 500,1000 , and $1500 \mathrm{mg} / \mathrm{kg}$ bw via gavage. To evaluate the protective effects of the extract, benzo[a]pyrene $(\mathrm{B}[\mathrm{a}] \mathrm{P})$ and cyclophosphamide $(\mathrm{CP})$ were chosen as DNA damage inducers. Genotoxicity and antigenotoxicity were evaluated by the comet assay. Cytotoxicity, mutagenicity, and antimutagenicity were evaluated by the micronucleus test in bone marrow and peripheral blood. The biochemical parameters of oxidative stress were evaluated by the quantification of catalase activity (CAT) and reduced glutathione (GSH) in total blood, liver and kidney, and malondialdehyde (MDA), in liver and kidney. No genotoxic, cytotoxic, or mutagenic effect was found on mice exposed to the extract. The extract depleted the number of damaged nucleoids in total blood and the number of micronucleus (MN) in both cell types. The extract was able to increase CAT activity and GSH levels and decrease MDA levels after treatment with $\mathrm{B}[\mathrm{a}] \mathrm{P}$ and $\mathrm{CP}$. The results indicate that the $S$. dulcis extract has potential to be used as preventive compound against DNA damage caused by $\mathrm{CP}$ and $\mathrm{B}[\mathrm{a}] \mathrm{P}$.
\end{abstract}

Keywords: Comet assay, micronucleus test, Spondias dulcis, cytotoxicity, mutagenicity.

Received: February 27, 2018; Accepted: January 15, 2019.

\section{Introduction}

The use of plants for medical purposes has always been a common practice all over the world. Medicinal plants are considered safe and of low cost, and are known to promote health (Partap et al., 2012). Although some plants possess therapeutic advantages, they can contain harmful, potentially toxic, and mutagenic substances (Lather et al., 2011; Cuyacot et al., 2014; Ferreira-Machado et al., 2014). The Anacardiaceae family is a group of tropical flowering plants that bears drupe fruits. This family comprises several genera that possess economic importance such as the genus Spondias. This genus consists of approximately 8 to 12 species that bear edible fruits and is distributed across tropical regions in the world (Narain et al., 2004). Spondias dulcis

Send correspondence to Leandra E. Kerche. Faculdade de Medicina, Universidade do Oeste Paulista, 700 R. José Bongiovani, 19050-920, Presidente Prudente, SP, Brazil. E-mail: leakerche@unoeste.br.

* These authors contributed equally to this work.
(S. dulcis) is a tropical species native from the region that spans from Melanesia through Polynesia, and its fruits are known as cajamanga, Hog plum, or golden apple. S. dulcis fruit is commonly used as food, but other parts of this plant are used as remedy. In Cambodia, the bark is used as remedy for diarrhea (Morton, 1987), in eyesight enhancement, and eye infections (Rahmatullah et al., 2009), and the fruit is used for itchiness, internal ulceration, sore throat, and skin inflammation (Wiart, 2006). Certain studies have shown medicinal properties of $S$. dulcis, such as induction of peritoneal macrophages activity (Sarker et al., 2012) and antidiabetic activity (Jantan, 2010). But to date, there is no study evaluating possible cytotoxic and mutagenic effects of $S$. dulcis bark extracts, nor its protective effects against DNA damage induced by chemical compounds.

Different types of mutagenic compounds are present in daily life. Benzo[a]pirene $(\mathrm{B}[\mathrm{a}] \mathrm{P})$ can be found in many foods, as smoked meat products and cigarette smoke, being related with lung cancer development (Ince et al., 2017; Yao et al., 2017). B[a]P belongs to the group of polycyclic 
aromatic hydrocarbons (PAHs) and due to its lipophilic nature, $\mathrm{B}[a] \mathrm{P}$ easily crosses the cell membrane and it has to be metabolized in order to be removed from the system. Inside the cell, $\mathrm{B}[a] \mathrm{P}$ is converted into the carcinogen 7,8-dihydrodiol-9,10-epoxide (BPDE) that can form adducts with guanines since it can covalently bind to DNA (IARC Working Group on the Evaluation of Carcinogenic Risks to Humans and International Agency for Research on Cancer, 2010; Shi et al., 2017). Christmann et al. (2016) showed that BPDE activates a network of transcriptional alterations of DNA repair and translation DNA synthesis (TLS) genes, leading to protection against cell death and an increased yield of mutations in the survivor cells. As an example, BPDE-DNA adducts in TP53 tumor suppressor gene can induce a mutational profile that is usually found in lung cancer tissue from cigarette smokers (Denissenko et al., 1996). Many of the mutagenic compounds are also used as treatment for various diseases. Cyclophosphamide (CP) is a widely used drug in cancer and non-malign diseases, however it can cause several side effects. (Drimal et al., 2006; Perini et al., 2007; Song et al., 2014). CP affects DNA through its alkylating properties and free radical production (Zhang et al., 2005; Sloczynska et al; 2014). The toxic effects associated with the administration of $\mathrm{CP}$ are mainly due to oxidative stress from the increase in the formation of superoxide radicals and hydrogen peroxide (Ettawa et al., 2016; Gunes et al., 2017).

Therefore, the aim of the present study was to evaluate for the first time possible cytotoxic and mutagenic effects as well as the protective effects of $S$. dulcis bark ethanolic extracts in vivo on $\mathrm{CP}$ - and $\mathrm{B}[\mathrm{a}] \mathrm{P}$-induced mutagenic damage, using the comet assay and micronucleus test. The extract' effects on biochemical oxidative stress parameters, such as catalase (CAT), glutathione (GSH), and malondialdehyde (MDA), were assessed in liver, kidney, and total blood.

\section{Materials and Methods}

\section{Chemicals}

Cyclophosphamide (CP) (CAS: 50-18-0) and ben$\mathrm{zo}[a]$ pirene $(\mathrm{B}[a] \mathrm{P})(\mathrm{CAS}: 50-32-8)$ were purchased from Sigma Chemical Co. (St. Louis, MO), diluted in distilled water and saline, respectively, and used as positive controls and as DNA damage-inducing agents in the tests concerning possible protective effects.

\section{Plant material and extract preparation}

A voucher of the plant is deposited in the Universidade Estadual de Maringá herbarium with the code HUEM 24319. The fresh stem bark of S. dulcis were washed with water immediately after collection in the plant nursery of Universidade do Oeste Paulista, Presidente Prudente, Brazil (UNOESTE). Then, the bark was chopped into small pieces, air dried at room temperature for about 10 days, and turned into powder $(1 \mathrm{~kg})$, which was infused in 6
$\mathrm{L}$ of pure ethanol for 7 days at room temperature $\left(23^{\circ} \mathrm{C} \pm\right.$ 5). After 7 days, the extract was filtered through cotton plugs and then through a Whatman No. 1 filter paper. The extract was concentrated under reduced pressure below 50 ${ }^{\circ} \mathrm{C}$ through rotatory vacuum evaporator (RE200 Sterling, UK). The concentrated extract was stored at $4{ }^{\circ} \mathrm{C}$.

\section{Pharmacognostic characterization}

After extraction, thin layer chromatography (TLC) was carried out on silica gel plates with fluorescence indicator (Macherey-Nagel), according to Wagner and Bladt (2001). The solvent system was ethyl acetate, acetic acid, formic acid, distilled water (100:11:11:26) eluted with filter paper. After the elution of the extracts, the plates were dried out in room temperature, revealed with diphenylboryloxyethylamine (NP) (Sigma-Aldrich), and placed under an UV lamp (365 nm).

The total phenolic content of the extract was determined by the Folin-Ciocalteu method (Kaur and Kapoor, 2002). Briefly, $200 \mu \mathrm{L}$ of crude extract ( $1 \mathrm{mg} / \mathrm{mL})$ was added to $3 \mathrm{~mL}$ of distilled water, mixed thoroughly with 0.5 $\mathrm{mL}$ of Folin-Ciocalteu reagent for $3 \mathrm{~min}$, followed by the addition of $2 \mathrm{~mL}$ of $20 \%$ (w/v) sodium carbonate. The mixture was allowed to stand for $60 \mathrm{~min}$ in the dark, and absorbance was measured at $650 \mathrm{~nm}$. The total phenolic content was calculated from the calibration curve, and the results were reported as $\mathrm{mg}$ of gallic acid equivalent per $\mathrm{g}$ dry weight.

The total flavonoid content of crude extract was determined according to Rolim et al. (2005) with modifications. The concentration of total flavonoids was determined spectrophotometrically as rutin equivalents compared to the standard curve of rutin. Standard rutin $(10 \mathrm{mg})$ was dissolved in methanol and acetic acid $0.02 \mathrm{M}(99: 1)$ to concentrations of $12.5,25,50,75$ and $85 \mathrm{mg} / \mathrm{mL}$. The absorbance measurements were obtained at $361 \mathrm{~nm}$. The methanol and acetic acid mixture was used as a solvent for the preparation of the sample solution. Analysis was performed in triplicates and the results are presented as $\%$ of total flavonoids.

\section{Animals}

The experimental protocols for this study were approved by the Local Ethics Committee for Animal Use (CEUA) of UNOESTE, register No. 2425/2015. Male and female albino Swiss mice (Mus musculus), aged 7-8 weeks and weighing $\sim 30 \mathrm{~g}$ at the beginning of the experiments, were used for the comet assay, micronucleus test, and biochemical parameters analysis. They were obtained from the mouse-breeding colony at the Universidade do Oeste Paulista and were kept individually in polypropylene cages following the conditions for animal care recommended by the Canadian Council on Animal Care (Olfert et al., 1993). The mice $(n=120)$ were divided into groups of 10 (five males and five females) for each treatment and these mice were the same for all the end points (comet assay, micronucleus test, and biochemical parameters). 


\section{Experimental design}

The mice received water and food ad libitum throughout the treatment period ( $24 \mathrm{~h})$. Firstly, the biological effects (cytotoxic, genotoxic, mutagenic, and oxidative stress generation) of $S$. dulcis extracts were evaluated at three acute doses: 500,1000 , and $1500 \mathrm{mg} / \mathrm{kg}$, once via gavage. Since no other study evaluate these parameters, these doses were based on the solubility of the bark extract in distilled water. A negative control group with distilled water and two positive control groups with $\mathrm{CP}(40 \mathrm{mg} / \mathrm{kg}$ bw) and $\mathrm{B}[\mathrm{a}] \mathrm{P}(9 \mathrm{mg} / \mathrm{kg}$ bw) were established.

The protective effects of the extract was also assessed. For this, CP $(40 \mathrm{mg} / \mathrm{kg}$ bw $)$ was administrated in a single i.p. dose $1 \mathrm{~h}$ after the plant extract was administered via gavage, and $\mathrm{B}[a] \mathrm{P}(9 \mathrm{mg} / \mathrm{kg}$ bw $)$ was administrated in a single s.c. dose simultaneously to the administration of the extract via gavage. A negative control group was established with distilled water.

After the treatment period $(24 \mathrm{~h})$, the mice were put under anesthesia with $10 \%$ chloral hydrate i.p. $(4 \mathrm{~mL} / \mathrm{kg}$ bw), total blood was collected from the heart and peripheral blood cells were collected from the tail vein. The animals were euthanized by cervical dislocation, and liver, kidneys, and femurs were collected.

\section{Cytotoxicity and micronucleus test in mouse bone marrow}

Bone marrow was removed $24 \mathrm{~h}$ after the treatment. Briefly, the bone marrow was flushed out of the femurs in a centrifuge tube with fetal calf serum. The bone marrow cells were collected by centrifugation at $1000 \mathrm{rpm}$ for 10 $\mathrm{min}$, and the pellet was resuspended in $0.3 \mathrm{~mL}$ of supernatant for the slide preparation. A drop of the suspension was smeared on a clean slide, air-dried, fixed in absolute methanol for $10 \mathrm{~min}$, and stained in the following day with Giemsa (diluted with phosphate buffer, pH 6.8).

Cytotoxicity was measured using the percentage of polychromatic erythrocytes (PCEs) among 1000 erythrocytes (PCEs/PCEs + normochromatic erythrocytes (NCEs)). For the micronucleus test, three thousand PCEs were analyzed (1000 per slide in triplicate), and the number of micronucleated PCEs (MNPCEs) was recorded (Schmid, 1975). The percentage of reduction in micronucleated cells $(\% \mathrm{R})$ was calculated using the formula: $\% \mathrm{R}$ $=[($ mean in $\mathrm{A}-$ mean in $\mathrm{B}) /($ mean in $\mathrm{A}-$ mean in $\mathrm{C})] 100$, where $\mathrm{A}$ is the group treated with positive control (CP or $\mathrm{B}[a] \mathrm{P}), \mathrm{B}$ is the group treated with different doses of the extract plus positive control, and $\mathrm{C}$ represents the group treated with distilled water (negative control group) (Waters et al., 1990).

\section{Comet assay and micronucleus test of peripheral blood cells}

The comet assay $(\mathrm{pH}>13)$ was conducted according to the protocols of Tice et al. (2000) and Singh et al. (1988). The comet assay detects initial and/or acute DNA damage even after short exposures. Peripheral blood $(10 \mu \mathrm{L})$ was mixed with low melting point agarose $(0.5 \%), 180 \mu \mathrm{L}$, and spread onto microscope slides precoated with normal melting point agarose $(1.5 \%)$ constituting a slide with two layers of agarose. The cells were covered with a coverslip and maintained at $4{ }^{\circ} \mathrm{C}$ for $10 \mathrm{~min}$. Coverslips were removed ant the slides were immersed in a freshly prepared lysis solution consisting of $2.5 \mathrm{M} \mathrm{NaCl}, 100 \mathrm{mM}$ ethylenediaminetetraacetic acid (EDTA), 10\% dimethylsulfoxide, 1\% Triton X-100, and $10 \mathrm{mM}$ Tris, $\mathrm{pH} 10$, for $60 \mathrm{~min}$ at $4{ }^{\circ} \mathrm{C}$. After lysis, the slides were placed in a horizontal electrophoresis unit containing $300 \mathrm{mM} \mathrm{NaOH}$ and $1 \mathrm{mM}$ EDTA at $\mathrm{pH}>13$ and left for $20 \mathrm{~min}$ to denature the DNA. Electrophoresis was run for $20 \mathrm{~min}$ at $1 \mathrm{~V} / \mathrm{cm}(25 \mathrm{~V}$ and $300 \mathrm{~mA})$. Slides were subsequently immersed in a neutralization buffer (0.4 M Tris $-\mathrm{HCl}, \mathrm{pH} 7.5)$ for $15 \mathrm{~min}$. After being dried at ambient temperature, slides were fixed in ethanol for 5 min and stored until analysis. After removal from storage, each slide was stained with $30 \mu \mathrm{L}$ 4',6-Diamine-2'phenylindole dihydrochloride (DAPI) $(1 \mathrm{mg} / \mathrm{mL})$ and immediately analyzed in a fluorescence microscopy (Olympus). For each treatment, the extent and distribution of DNA damage indicated by the comet assay was evaluated by examining 100 randomly-selected and non-overlapping cells on the slides (i.e., 300 cells per treatment). On each slide, the cells were visually scored and allocated to one of four classes (0, 1, 2, and 3) (Speit and Hartmann, 2005) and the total score for 300 comets was obtained according to the formula of Manoharan and Banerjee (1985), as shown below:

$$
\text { Score }=\left(1 n_{1}+2 n_{2}+3 n_{3}\right)
$$

where $n$ is the number of cells in each class analyzed. The total score could therefore range from 0 to 300 .

The micronucleus test on peripheral blood cells was performed according to the protocol described by Hayashi et al. (1990), which uses slides prestained with acridine orange. Blood sampling was performed $24 \mathrm{~h}$ after the treatment. The sample was placed in the center of a prestained slide and covered with a coverslip (24 $50 \mathrm{~mm}$ ). The slides were stored in the dark at $-20^{\circ} \mathrm{C}$ until the cytological examination was performed. The cell preparations were examined under a fluorescence microscope (Olympus) with a blue $(488 \mathrm{~nm})$ excitation filter and a yellow $(515 \mathrm{~nm})$ emission (barrier) filter using an immersion objective. A total of 3000 reticulocytes per treated animal were analyzed (1000 per slide in triplicate), and the number of micronucleated reticulocytes (MNRETs) was counted. The percentage of reduction in micronucleated cells $(\% \mathrm{R})$ was calculated using the formula: $\% \mathrm{R}=[($ mean in $\mathrm{A}-$ mean in $\mathrm{B}) /($ mean in $\mathrm{A}-$ mean in $\mathrm{C})] 100$, where $\mathrm{A}$ is the group treated with positive control $(\mathrm{CP}$ or $\mathrm{B}[a] \mathrm{P})$, B is the group treated with different doses of the extract plus positive control, and $\mathrm{C}$ represents the group treated with distilled water (negative control group) (Waters et al., 1990). 


\section{Evaluation of CAT activity and GSH concentrations in total blood}

For CAT analysis assay, the hemolysate was diluted 1:20 in $0.1 \mathrm{M}$ phosphate buffer, $\mathrm{pH} 7.0$, and the assay was performed in triplicate. CAT activity was measured in 50 $\mathrm{mM}$ phosphate buffer ( $\mathrm{pH} 7.0$ ) by monitoring the decrease in absorbance at $240 \mathrm{~nm}$ for $30 \mathrm{~s}$ after the addition of 10 $\mathrm{mM}$ hydrogen peroxide. One unit of CAT activity is the amount of enzyme that decomposes $1 \mu \mathrm{M} \mathrm{H}_{2} \mathrm{O}_{2}$ per min at $25^{\circ} \mathrm{C}$ (Aebi, 1984). The erythrocyte CAT activity was expressed as $\kappa / \mathrm{g}$ protein. $\mathrm{min}^{-1}$.

Reduced GSH concentrations were estimated using the method of Ellman (1959). Briefly, erythrocytes (0.3 $\mathrm{mL})$ were hemolyzed using $10 \%$ Triton X-100 $(0.1 \mathrm{~mL})$ and precipitated with $200 \mu \mathrm{L}$ of $20 \%$ trichloroacetic acid (TCA). After centrifugation at 5,000 rpm for $10 \mathrm{~min}$, color was developed in the supernatant by adding $50 \mu \mathrm{L}$ of 10 $\mathrm{mM}$ 5-5'-dithio-bis (2-nitrobenzoic acid) (DTNB), and the optical density was recorded at $412 \mathrm{~nm}$ using $\alpha$-cysteine as reference standard. The GSH content was expressed as nanomoles per milliliter $(\mathrm{nM} / \mathrm{mL})$ of blood.

\section{TBARS and GSH levels in kidney and liver}

Thiobarbituric acid reactive substances (TBARS) measurements were done according to the method of Uchiyama and Mihara (1978) with modifications. Briefly, kidney or liver tissue $(200 \mathrm{mg})$ was homogenized in $5.0 \mathrm{~mL}$ ice-cold $1.15 \% \mathrm{KCl}$, and an aliquot $(200 \mu \mathrm{L})$ of homogenate was mixed with $400 \mu \mathrm{L}$ of the TBA solution (1\% TBA, $50 \mathrm{mM} \mathrm{NaOH}$ and $0.1 \mathrm{mM} \mathrm{BHT}$ ) and $200 \mu \mathrm{L}$ of $7 \%$ phosphoric acid. The mixtures were incubated in a boiling bath for $15 \mathrm{~min}$. After cooling the tubes on ice, $1.5 \mathrm{~mL}$ of $n$-butanol was added and the reaction mixture was centrifuged at $6,000 \mathrm{rpm}$ for $10 \mathrm{~min}$. The absorbance of the supernatant was read at $532 \mathrm{~nm}$, and the TBARS concentrations were calculated using tetraethoxy propane as a reference standard. The TBARS concentrations in tissue was reported as nmol MDA/g of tissue.

Reduced GSH concentrations were estimated using the method of Ellman (1959). Briefly, the same homogenized kidney or liver tissue cited above was diluted in water (1:4), precipitated with 50\% TCA and centrifuged at 6,000 rpm for $10 \mathrm{~min}$. An aliquot $(500 \mu \mathrm{L})$ of the supernatant was added to $2.0 \mathrm{ml}$ Tris-EDTA buffer $(0.2 \mathrm{M}, \mathrm{pH} 8.9)$ and 100 $\mu \mathrm{L}$ of $0.01 \mathrm{M}$ DTNB in methanol. The solution was incubated at room temperature for $15 \mathrm{~min}$ and read at $412 \mathrm{~nm}$ using $\alpha$-cysteine as reference standard (Sedlak and Lindsay, 1968). The results were reported as nmol GSH/g of tissue.

\section{Statistical analysis}

All results are reported as mean \pm standard deviation (SD). No differences were observed between males and females for all parameters analyzed, and thus, means were calculated for all treated groups using both females and males (Student's $t$-test, $p>0.05$ ). The results of the cytotoxicity were compared between the treatment groups and the negative control group using one-way ANOVA and Dunnett's test (at significance level $p<0.05$ ) in GraphPad Prism 6 (GraphPad Software, USA). For assessment of the biochemical parameters, mutagenicity, and protective effects, all groups were compared using one-way ANOVA and Tukey's test $(p<0.05)$.

\section{Results}

\section{Pharmacognostic characterization}

The TLC of the extract was carried out using flavonoids (quercetin and rutin) and tannins (tannic and gallic acid) as references, and the results showed that this extract presents quercetin and rutin in its constitution (Figure 1).

The analysis of total phenolic content of the extract showed a concentration of $518 \mathrm{mg}$ of phenolic acids in $1 \mathrm{~g}$ of the extract, based on gallic acid standard curve ( $\mathrm{y}=$ $\left.0.007 x+0.0027, R^{2}=0.9978\right)$. The analysis of total flavonoid content of the extract showed a concentration of 185 $\mathrm{mg}$ of flavonoids in $1 \mathrm{~g}$ of the extract, based on rutin standard curve $\left(\mathrm{y}=0.0154 \mathrm{x}-0.0044, \mathrm{R}^{2}=0.9926\right)$.

\section{Mouse bone marrow}

\section{Cytotoxicity}

Results from the ANOVA and Dunnett's test showed no significative difference between all treated groups and the negative control group (distilled water). Therefore, these concentrations of the extract $(500,1000$, and 1500 $\mathrm{mg} / \mathrm{kg} \mathrm{bw}$ ), associated or not to the positive controls (CP and $\mathrm{B}[a] \mathrm{P})$, had no cytotoxic effects in the bone marrow of mice $(p<0.05)$ (Figure 2).

\section{Micronucleus}

In bone marrow, the number of micronuclei did not change after treatment with either 500, 1000, and 1500 $\mathrm{mg} / \mathrm{kg}$ bw of the extract (Figure 3). The bone marrow was also used to analyze protective effects of $S$. dulcis ethanolic bark extract. A large protective effect can be observed for

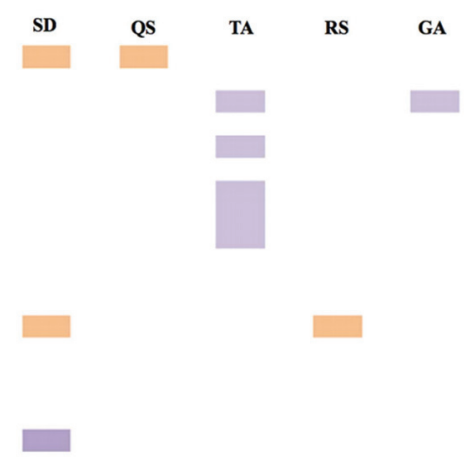

Figure 1 - Thin layer chromatography of Spondias dulcis Forst F bark ethanolic extract. SD, S. dulcis extract; QS, Quercetin standard; TA, Tannic acid standard; RS, Rutin standard; GA, Gallic acid standard. 


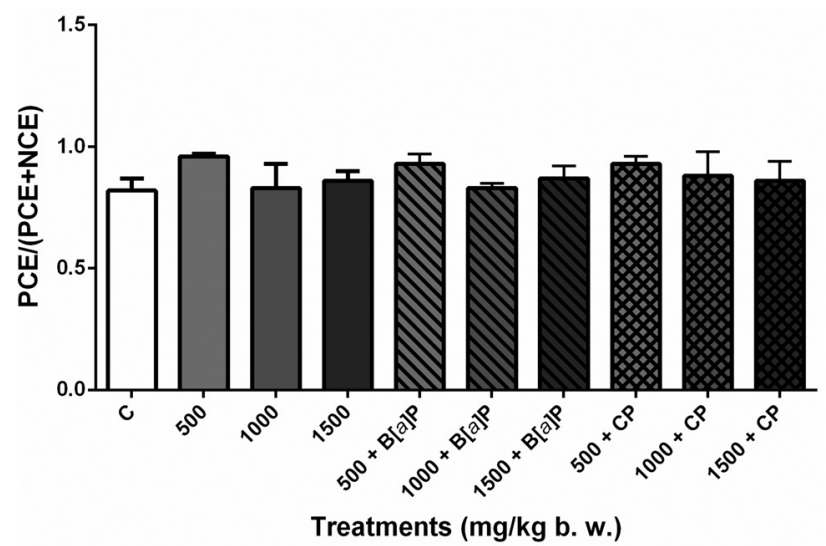

Figure 2 - Evaluation of cytotoxicity in mouse bone marrow cells after acute treatment with $S$. dulcis bark ethanolic extract (500, 1000, and 1500 $\mathrm{mg} / \mathrm{kg} \mathrm{bw}$ ) associated or not with $\mathrm{B}[a] \mathrm{P}$ and $\mathrm{CP}$. Calculation of $\mathrm{PCE} /(\mathrm{PCE}+\mathrm{NCE})$ on examination of 1000 erythrocytes. Shown are means \pm SD for 10 animals (male and female) from each treatment. ANOVA and Dunnett's test $(p<0.05)$. PCE: polychromatic erythrocyte; NCE: normochromatic erythrocyte; $\mathrm{C}$ : distilled water; $\mathrm{B}[a] \mathrm{P}$ : benzo $[a]$ pyrene; $\mathrm{CP}$ : cyclophosphamide.

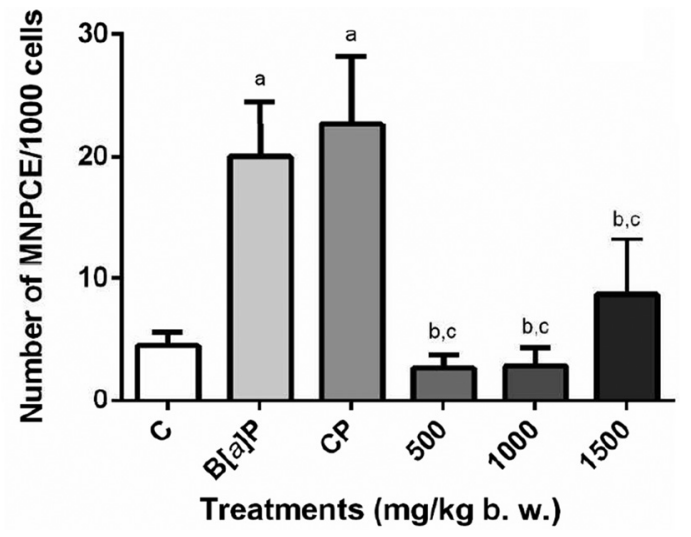

Figure 3 - Frequency of MNPCEs in mouse bone marrow after acute treatment with three different concentrations $(500,1000$, and $1500 \mathrm{mg} / \mathrm{kg} \mathrm{bw})$ of the $S$. dulcis bark ethanolic extract. Shown are the means \pm SD for 10 animals (male and female) from each treatment. Statistical analysis was performed using ANOVA and Tukey's test $(p<0.05)$. 'Statistically different from negative control group; ${ }^{b}$ statistically different from $\mathrm{B}[a] \mathrm{P}$ con-

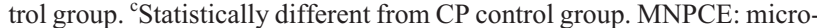
nucleated polychromatic erythrocyte; $\mathrm{C}$ : distilled water; $\mathrm{B}[a] \mathrm{P}$ : benzo $[a]$ pyrene; CP: cyclophosphamide.

both DNA damage inducers $(\mathrm{B}[a] \mathrm{P}$ and $\mathrm{CP})$. In bone marrow, the greatest protection occurred for the dose 500 $\mathrm{mg} / \mathrm{kg}$ bw associated with CP (87.18\%) (Table 1).

\section{Peripheral blood}

\section{Comet assay}

Results on DNA stability are shown in Table 2. Exposure to $\mathrm{B}[a] \mathrm{P}$ and $\mathrm{CP}$ increased the number of damaged nucleoids while no evidence of genotoxic effect was seen after the exposure of the cells to $S$. dulcis extract (500, 1000 and $1500 \mu \mathrm{g} / \mathrm{mL}$ ) under the conditions of the test. The re-
Table 1 - Numbers of micronucleated PCEs (MNPCE) from mouse bone marrow and percent damage reduction $(\% \mathrm{R})$ obtained in the determination of in vivo antimutagenicity of Spondias dulcis Forst F. bark ethanolic extract at three concentrations, and the respective controls.

\begin{tabular}{lccc}
\hline $\begin{array}{l}\text { Treatments } \\
(\mathrm{mg} / \mathrm{kg} \text { b.w. }\end{array}$ & No. animals & $\begin{array}{c}\text { MNPCE } \\
(X \pm \mathrm{SD})\end{array}$ & $\% \mathrm{R}$ \\
\hline $\mathrm{C}$ & 10 & $4.50 \pm 1.05^{\mathrm{a}}$ & - \\
$\mathrm{B}[a] \mathrm{P}$ & 10 & $20.00 \pm 4.45^{\mathrm{b}}$ & - \\
$\mathrm{CP}$ & 10 & $22.67 \pm 5.50^{\mathrm{c}}$ & - \\
$500+\mathrm{B}[a] \mathrm{P}$ & 10 & $8.33 \pm 1.51^{\mathrm{a}}$ & $75.29 \%$ \\
$1000+\mathrm{B}[a] \mathrm{P}$ & 10 & $9.17 \pm 3.25^{\mathrm{a}}$ & $69.87 \%$ \\
$1500+\mathrm{B}[a] \mathrm{P}$ & 10 & $9.17 \pm 1.52^{\mathrm{a}}$ & $69.87 \%$ \\
$500+\mathrm{CP}$ & 10 & $6.83 \pm 0.79^{\mathrm{a}}$ & $87.18 \%$ \\
$1000+\mathrm{CP}$ & 10 & $8.00 \pm 1.90^{\mathrm{a}}$ & $80.74 \%$ \\
$1500+\mathrm{CP}$ & 10 & $8.33 \pm 1.96^{\mathrm{a}}$ & $78.92 \%$ \\
\hline
\end{tabular}

Different letters indicate statistical significance. $X \pm \mathrm{SD}$, mean \pm standard deviation; $\mathrm{C}$, distilled water; $\mathrm{B}[a] \mathrm{P}$, benzo $[a]$ pyrene; $\mathrm{CP}$, cyclophosphamide; $p<0.05$, Statistical Analysis was done using one-way ANOVA and Tukey's Test.

sults of experiments in which the protective properties of the $S$. dulcis extract on DNA damage induced by $\mathrm{B}[\mathrm{a}] \mathrm{P}$ and $\mathrm{CP}$ are summarized in Table 3 . All doses tested were able to reduce the number of damaged nucleoids to levels similar to the negative control

\section{Micronucleus}

The number of micronuclei in blood induced by the extract from $S$. dulcis is in the same range as distilled water, demonstrating that the extract has no genotoxic effects in acute treatment. On the other hand, administration of $\mathrm{B}[a] \mathrm{P}$ and $\mathrm{CP}$ resulted in a significant increase of micronucleus. Peripheral blood was also used to analyze protective effects of $S$. dulcis (Figure 4). A great protective effect can be observed for both DNA damage inducers $(\mathrm{B}[a] \mathrm{P}$ and $\mathrm{CP})$. In peripheral blood, the greatest protection occurred for the dose of $500 \mathrm{mg} / \mathrm{kg}$ bw associated with B[a]P (98\%) $(p<$ 0.05) (Table 4).

\section{CAT and GSH in total blood}

Figure 5 shows CAT activity and GSH concentration among the different groups. None of the three doses of the extract $(500,1000$, and $1500 \mathrm{mg} / \mathrm{kg}$ bw) altered CAT activity and GSH levels in erythrocytes. B[a]P and CP treatments depleted severely the CAT activity and quantity of GSH in the erythrocytes, and the association of the extract in the doses of 500 and $1000 \mathrm{mg} / \mathrm{kg}$ bw with these chemicals $(\mathrm{B}[a] \mathrm{P}$ and $\mathrm{CP})$ increased the activity of CAT and the levels of GSH in the erythrocytes similarly to the negative control $(p<0.05)$.

\section{TBARS and GSH in tissue}

The levels of the oxidative stress biomarkers TBARS and GSH in liver and TBARS and GSH in kidney are shown in Figures 6 and 7, respectively. 
Table 2 - Number of nucleoids observed in each comet class in 300 cells analyzed per treatment, and their respective mean scores when assessing the genotoxicity of Spondias dulcis at three different concentrations in mice.

\begin{tabular}{|c|c|c|c|c|c|c|c|}
\hline \multirow[t]{2}{*}{ Treatment $(\mu \mathrm{g} / \mathrm{mL})$} & \multicolumn{4}{|c|}{ Comet Class } & \multirow[t]{2}{*}{ Damaged nucleoids } & \multirow[t]{2}{*}{ Score } & \multirow[t]{2}{*}{$X \pm \mathrm{SD}$} \\
\hline & 0 & 1 & 2 & 3 & & & \\
\hline \multirow[t]{3}{*}{ Control } & 99 & 1 & 0 & 0 & 1 & 1 & $1.33 \pm 0.58$ \\
\hline & 98 & 2 & 0 & 0 & 2 & 2 & \\
\hline & 99 & 1 & 0 & 0 & 1 & 1 & \\
\hline \multirow[t]{3}{*}{$\mathrm{CP}$} & 66 & 28 & 3 & 3 & 34 & 43 & $44.0 \pm 6.56^{\mathrm{a}}$ \\
\hline & 66 & 30 & 4 & 0 & 34 & 38 & \\
\hline & 55 & 39 & 6 & 0 & 45 & 51 & \\
\hline \multirow[t]{3}{*}{$\mathrm{B}[a] \mathrm{P}$} & 87 & 13 & 0 & 0 & 13 & 13 & $12.67 \pm 1.53^{\mathrm{a}}$ \\
\hline & 87 & 12 & 1 & 0 & 13 & 14 & \\
\hline & 90 & 9 & 1 & 0 & 10 & 11 & \\
\hline \multicolumn{8}{|l|}{ Spondias dulcis } \\
\hline \multirow[t]{3}{*}{500} & 98 & 2 & 0 & 0 & 2 & 2 & $2.330 .58^{b c}$ \\
\hline & 97 & 3 & 0 & 0 & 3 & 3 & \\
\hline & 98 & 2 & 0 & 0 & 2 & 2 & \\
\hline \multirow[t]{3}{*}{1000} & 98 & 2 & 0 & 0 & 2 & 2 & $2.33 \pm 1.53^{b c}$ \\
\hline & 97 & 2 & 1 & 0 & 2 & 4 & \\
\hline & 99 & 1 & 0 & 0 & 1 & 1 & \\
\hline \multirow[t]{3}{*}{1500} & 99 & 1 & 0 & 0 & 1 & 1 & $2.33 \pm 1.53^{\mathrm{b} c}$ \\
\hline & 97 & 2 & 1 & 0 & 3 & 4 & \\
\hline & 98 & 2 & 0 & 0 & 2 & 2 & \\
\hline
\end{tabular}

Control (distilled water); $\mathrm{CP}$, cyclophosphamide; $\mathrm{B}[a] \mathrm{P}$, benzo $[a]$ pyrene; $X \pm \mathrm{SD}$, mean \pm standard deviation. ${ }^{\mathrm{a}}$ Significantly different from control, ${ }^{\mathrm{b}}$ significantly different from $\mathrm{CP}$, ${ }^{\mathrm{c}}$ significantly different from $\mathrm{B}[a] \mathrm{P}(p<0.05)$.

Table 3 - Number of nucleoids observed in each comet class in 300 cells analyzed per treatment, and their respective mean scores when assessing the antigenotoxicity effect of Spondias dulcis at three different concentrations in mice.

\begin{tabular}{|c|c|c|c|c|c|c|c|}
\hline \multirow[t]{2}{*}{ Treatment $(\mu \mathrm{g} / \mathrm{mL})$} & \multicolumn{4}{|c|}{ Comet Class } & \multirow[t]{2}{*}{ Damaged nucleoids } & \multirow[t]{2}{*}{ Score } & \multirow[t]{2}{*}{$X \pm \mathrm{SD}$} \\
\hline & 0 & 1 & 2 & 3 & & & \\
\hline \multirow[t]{3}{*}{ Control } & 99 & 1 & 0 & 0 & 1 & 1 & $1.33 \pm 0.58$ \\
\hline & 98 & 2 & 0 & 0 & 2 & 2 & \\
\hline & 99 & 1 & 0 & 0 & 1 & 1 & \\
\hline \multirow[t]{3}{*}{$\mathrm{CP}$} & 66 & 28 & 3 & 3 & 34 & 43 & $44.0 \pm 6.56^{\mathrm{a}}$ \\
\hline & 66 & 30 & 4 & 0 & 34 & 38 & \\
\hline & 55 & 39 & 6 & 0 & 45 & 51 & \\
\hline \multirow[t]{3}{*}{$\mathrm{B}[a] \mathrm{P}$} & 87 & 13 & 0 & 0 & 13 & 13 & $12.67 \pm 1.53^{\mathrm{a}}$ \\
\hline & 87 & 12 & 1 & 0 & 13 & 14 & \\
\hline & 90 & 9 & 1 & 0 & 10 & 11 & \\
\hline \multicolumn{8}{|l|}{ Spondias dulcis $+\mathrm{CP}$} \\
\hline \multirow[t]{3}{*}{500} & 96 & 4 & 0 & 0 & 4 & 4 & $7.0 \pm 3.0^{\mathrm{a} b}$ \\
\hline & 96 & 3 & 1 & 0 & 4 & 7 & \\
\hline & 90 & 10 & 0 & 0 & 10 & 10 & \\
\hline \multirow[t]{3}{*}{1000} & 99 & 1 & 0 & 0 & 1 & 1 & $3.0 \pm 2.0^{\mathrm{b}}$ \\
\hline & 98 & 1 & 1 & 0 & 2 & 3 & \\
\hline & 95 & 5 & 0 & 0 & 5 & 5 & \\
\hline \multirow[t]{3}{*}{1500} & 95 & 4 & 1 & 0 & 5 & 6 & $5.670 .58^{b}$ \\
\hline & 94 & 6 & 0 & 0 & 6 & 6 & \\
\hline & 95 & 5 & 0 & 0 & 5 & 5 & \\
\hline \multicolumn{8}{|c|}{ Spondias dulcis $+\mathrm{B}[a] \mathrm{P}$} \\
\hline & 96 & 4 & 0 & 0 & 4 & 4 & \\
\hline
\end{tabular}


Table 3 - cont.

\begin{tabular}{|c|c|c|c|c|c|c|c|}
\hline \multirow[t]{2}{*}{ Treatment $(\mu \mathrm{g} / \mathrm{mL})$} & \multicolumn{4}{|c|}{ Comet Class } & \multirow[t]{2}{*}{ Damaged nucleoids } & \multirow[t]{2}{*}{ Score } & \multirow{2}{*}{$X \pm \mathrm{SD}$} \\
\hline & 0 & 1 & 2 & 3 & & & \\
\hline \multirow[t]{3}{*}{500} & 100 & 0 & 0 & 0 & 0 & 0 & $2.3 \pm 2.1^{\mathrm{c}}$ \\
\hline & 97 & 3 & 0 & 0 & 3 & 3 & \\
\hline & 92 & 5 & 3 & 0 & 8 & 11 & \\
\hline \multirow[t]{3}{*}{1000} & 97 & 2 & 1 & 0 & 3 & 4 & $7.0 \pm 3.6^{\mathrm{ac}}$ \\
\hline & 94 & 6 & 0 & 0 & 1 & 6 & \\
\hline & 97 & 2 & 1 & 0 & 3 & 4 & \\
\hline \multirow[t]{2}{*}{1500} & 95 & 5 & 0 & 0 & 0 & 5 & $6.7 \pm 3.8^{\mathrm{ac}}$ \\
\hline & 90 & 9 & 1 & 0 & 2 & 11 & \\
\hline
\end{tabular}

Control (distilled water); $\mathrm{CP}$, cyclophosphamide; $\mathrm{B}[a] \mathrm{P}$, benzo $[a]$ pyrene; $X \pm \mathrm{SD}$, mean \pm standard deviation. ${ }^{\text {a }}$ Significantly different from negative control; ${ }^{\mathrm{b}}$ significantly different from $\mathrm{CP} ;{ }^{\mathrm{c}}$ significantly different from $\mathrm{B}[a] \mathrm{P}(p<0.05)$.

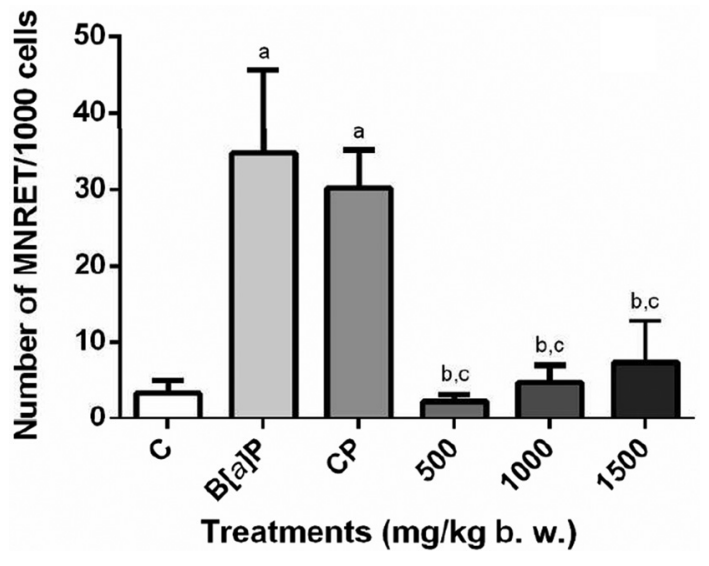

Figure 4 - Frequency of MNRETs in mouse peripheral blood after acute treatment with three different concentrations $(500,1000$, and $1500 \mathrm{mg} / \mathrm{kg}$ bw) of the $S$. dulcis bark ethanolic extract. The plot shown the means \pm SD for ten animals (male and female) from each treatment. Statistical analysis was performed using ANOVA and Tukey's test $(p<0.05)$. ${ }^{\text {a }}$ Statistically different from negative control group. ${ }^{b}$ Statistically different from $\mathrm{B}[a] \mathrm{P}$ control group; ${ }^{c}$ statistically different from CP control group. MNRET: micronucleated reticulocyte; $\mathrm{C}$ : distilled water; $\mathrm{B}[a] \mathrm{P}$ : benzo $[a]$ pyrene; CP: cyclophosphamide.

In the liver, mice treated with the concentrations of 500 and $1500 \mathrm{mg} / \mathrm{kg}$ bw of the extract did not show an increase in lipid peroxidation that was measured by the amount of MDA in the tissue $(p<0.05)$. On the other hand, $\mathrm{B}[a] \mathrm{P}$ and $\mathrm{CP}$ treatments enhanced the levels of MDA in the liver, and the association of the extract to these chemicals depleted the levels of MDA in the tissue to negative control levels $(p<0.05)$. In the kidney, the levels of MDA for the animals treated with the extract associated or not to the positive controls were similar to the negative control $(p<0.05)$. These results show that the $S$. dulcis extract significantly prevented the peroxidative effects of $\mathrm{B}[a] \mathrm{P}$ and $\mathrm{CP}$.

The treatment with $\mathrm{B}[a] \mathrm{P}$ and $\mathrm{CP}$ severely depleted GSH levels in liver tissue. For the treatment with the extract the only dose that did not deplete the levels of GSH, associated or not the positive controls $\mathrm{B}[a] \mathrm{P}$ and $\mathrm{CP}$, and maintained the levels similar to the negative control, was 500 $\mathrm{mg} / \mathrm{kg}$ bw. While all the concentrations tested did not de-
Table 4 - Numbers of micronucleated RETs (MNRET) from peripheral blood and percent damage reduction $(\% \mathrm{R})$ obtained in the determination of in vivo antimutagenicity of Spondias dulcis Forst F. bark ethanolic extract at three concentrations, and the respective controls.

\begin{tabular}{lccc}
\hline $\begin{array}{l}\text { Treatments } \\
(\mathrm{mg} / \mathrm{kg} \text { b.w. })\end{array}$ & N. of animals & $\begin{array}{c}\text { MNRET } \\
(X \pm \mathrm{SD})\end{array}$ & $\% \mathrm{R}$ \\
\hline $\mathrm{C}$ & 10 & $3.33 \pm 1.63^{\mathrm{a}}$ & - \\
$\mathrm{B}[\mathrm{a}] \mathrm{P}$ & 10 & $30.20 \pm 10.87^{\mathrm{b}}$ & - \\
$\mathrm{CP}$ & 10 & $34.75 \pm 4.97^{\mathrm{c}}$ & - \\
$500+\mathrm{B}[a] \mathrm{P}$ & 10 & $3.75 \pm 0.96^{\mathrm{a}}$ & $98.00 \%$ \\
$1000+\mathrm{B}[a] \mathrm{P}$ & 10 & $5.00 \pm 1.47^{\mathrm{a}}$ & $93.78 \%$ \\
$1500+\mathrm{B}[a] \mathrm{P}$ & 10 & $5.33 \pm 1.03^{\mathrm{a}}$ & $92.56 \%$ \\
$500+\mathrm{CP}$ & 10 & $7.80 \pm 1.63^{\mathrm{a}}$ & $85.77 \%$ \\
$1000+\mathrm{CP}$ & 10 & $8.17 \pm 2.40^{\mathrm{a}}$ & $84.60 \%$ \\
$1500+\mathrm{CP}$ & 10 & $10.33 \pm 2.39^{\mathrm{d}}$ & $77.72 \%$ \\
\hline
\end{tabular}

Different letters indicate statistical significance. $X \pm \mathrm{SD}$, mean \pm standard deviation; $\mathrm{C}$, distilled water; $\mathrm{B}[a] \mathrm{P}$, benzo $[a]$ pyrene; $\mathrm{CP}$, cyclophosphamide; $p<0.05$, Statistical analysis was done using one-way ANOVA and Tukey's Test.

plete the blood GSH levels, the results were different for the liver. In the kidney, all three concentrations tested (500, 1000 , and $1500 \mathrm{mg} / \mathrm{kg} \mathrm{bw}$ ) maintained the levels of GSH in the tissue, and $\mathrm{B}[a] \mathrm{P}$ and $\mathrm{CP}$ associated to the extract from $S$. dulcis was able to enhance the levels of GSH.

\section{Discussion}

It is very well known that phenolic compounds have the potential to exhibit multiple biological effects, including antioxidant activity (Huda-Faujan et al., 2009; Huang et al., 2016). According to various studies, phenolic compounds are effective in preventing many pathologies, such as cancer (Mocanu et al., 2015), inflammation (Biasi et al., 2011), diabetes (Szkudelski and Szkudelska, 2015), and cardiovascular diseases (Yamagata et al., 2015). The pharmacognostic characterization of the $S$. dulcis bark ethanolic extract showed the presence of flavonoids and phenolic acids in its constitution. Because of their chemical characteristics, phenolic acids can usually elicit primary prevention 


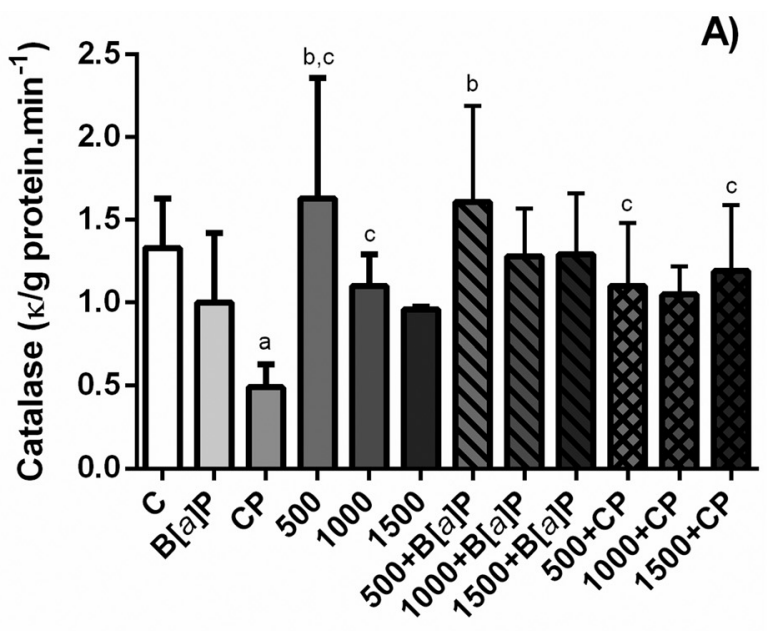

Treatments (mg/kg b. w.)

A)

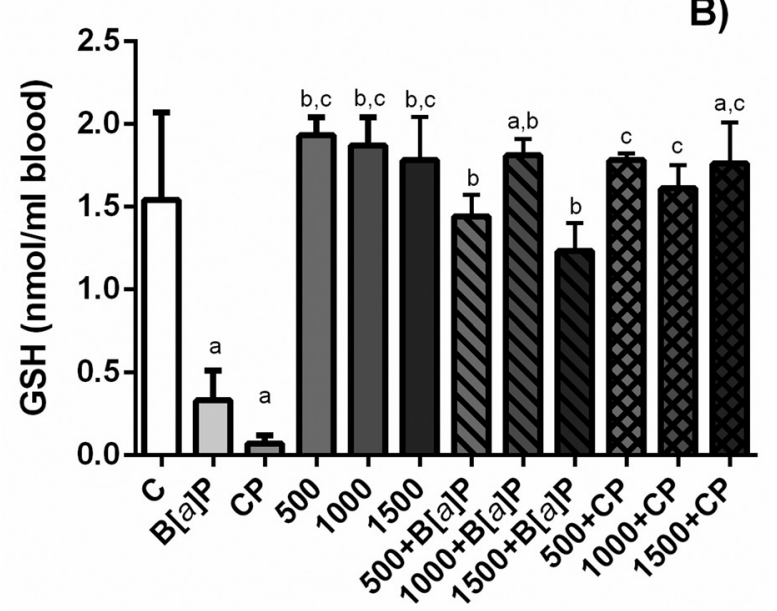

Treatments (mg/kg b. w.)

Figure 5 - Quantification of CAT (A) and GSH (B) in total blood of mouse treated with S. dulcis bark ethanolic extract (500, 1000, and 1500 mg/kg bw) associated or not to the positive controls $(\mathrm{B}[a] \mathrm{P}$ and $\mathrm{CP})$. Results are shown as means $\pm \mathrm{SD}$. ${ }^{\text {a }}$ Statistically different from negative control group; ${ }^{\mathrm{b}}$ statistically different from $\mathrm{B}[\mathrm{a}] \mathrm{P}$ control group; ${ }^{\mathrm{c}}$ statistically different from $\mathrm{CP}$ control group. CAT: catalase; GSH: glutathione; C: distilled water; $\mathrm{B}[a] \mathrm{P}$ : benzo $[a]$ pyrene; CP: cyclophosphamide. Statistical analysis performed using ANOVA and Tukey's test with significance threshold of $p<0.05$.

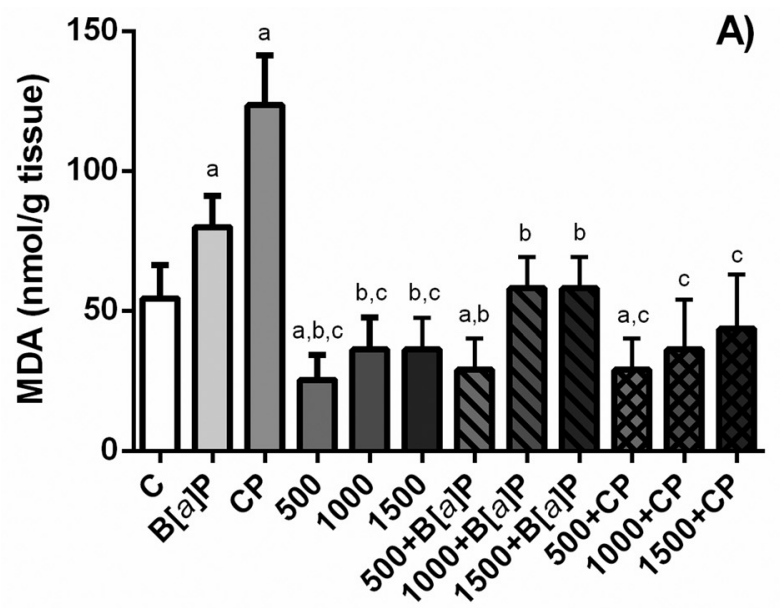

Treatments (mg/kg b. w.)

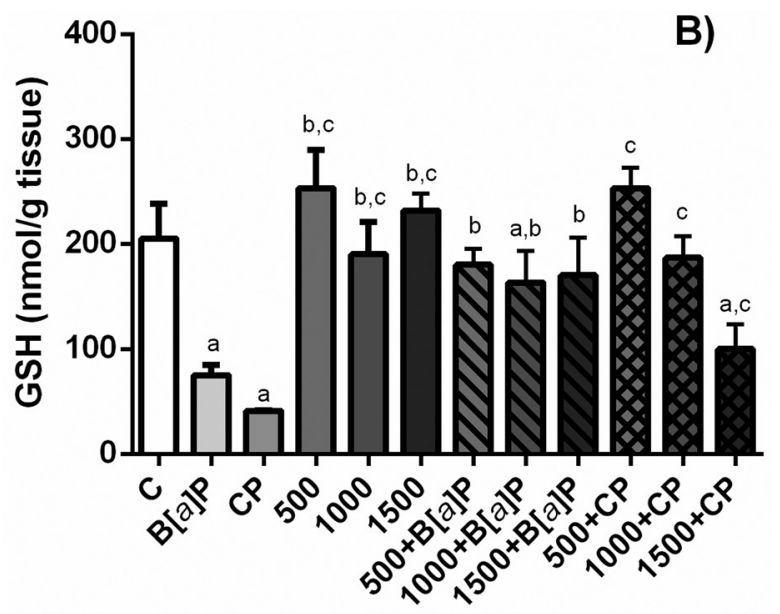

Treatments (mg/kg b. w.)

Figure 6 - Quantification of lipoperoxidation by measuring the formation of MDA, principal thiobarbituric acid-reactive specie (TBARS) (A) and GSH (B) in the liver of mouse treated with $S$. dulcis bark ethanolic extract $(500,1000$, and $1500 \mathrm{mg} / \mathrm{kg}$ bw) associated or not to the positive controls (B $[a] \mathrm{P}$ and $\mathrm{CP})$. Results are shown as means $\pm \mathrm{SD}$. ${ }^{\mathrm{a}}$ Statistically different from negative control group; ${ }^{\mathrm{b}}$ statistically different from $\mathrm{B}[\mathrm{a}] \mathrm{P}$ control group; ${ }^{\mathrm{c}}$ statistically different from CP control group. MDA: malondialdehyde; GSH: glutathione; C: distilled water; B $[a]$ P: benzo[ $a]$ pyrene; CP: cyclophosphamide. Statistical analysis performed using ANOVA and Tukey's test with significance threshold of $p<0.05$.

inhibiting mutations and cancer initiation in extracellular and intracellular media, preventing the uptake of mutagens and carcinogens, maintaining the DNA structure safe (De Flora and Ferguson, 2005). Flavonoids are composed of three rings (A, B, and $\mathrm{C}$ ) and the substitution of hydroxyl groups in these rings results in the successful scavenge of ROS, increasing their antioxidant capacity (Amic et al., 2007). Quercetin, one of the flavonoids found in the extract, is very active due to free $3-\mathrm{OH}$ groups that stabilize the B-ring for free radical scavenging ability (Rice-Evans et al., 1996). Other studies have proven the ability of quer- cetin to reduce DNA damage provoked by $\mathrm{B}[a] \mathrm{P}$ and $\mathrm{CP}$ (Hollman et al., 1997; Wilms et al., 2005; Abo-Zeid et al., 2018).

Anomalies and initial lesions on DNA, such as single and double strand breaks and crosslinks, can be detected by the comet assay. These DNA damages can either be repaired or lead to cytotoxicity and mutations, and the comet assay detects these lesions in early stages. $\mathrm{B}[a] \mathrm{P}$ and $\mathrm{CP}$ were chosen as positive controls, as they can elicit DNA damage. As expected, $\mathrm{B}[a] \mathrm{P}$ and $\mathrm{CP}$ were genotoxic to the mouse cells, as indicated by the rise in the number of dam- 


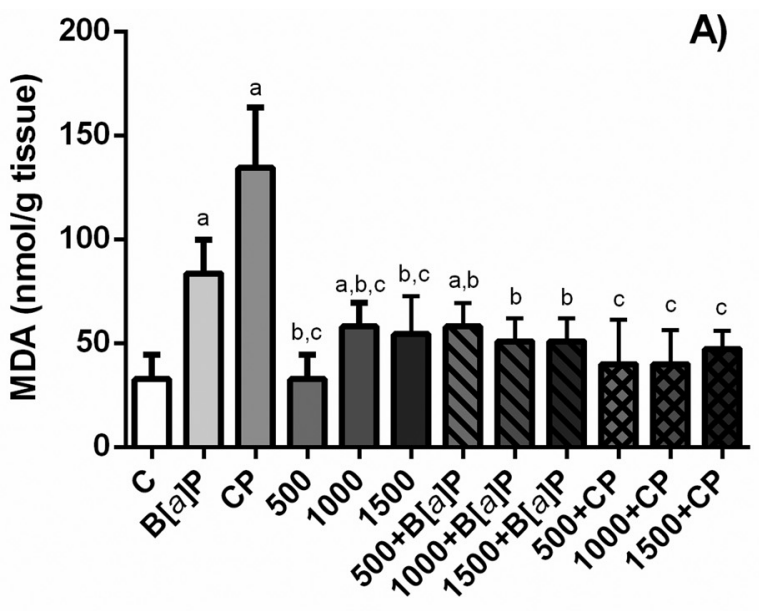

Treatments (mg/kg b. w.)

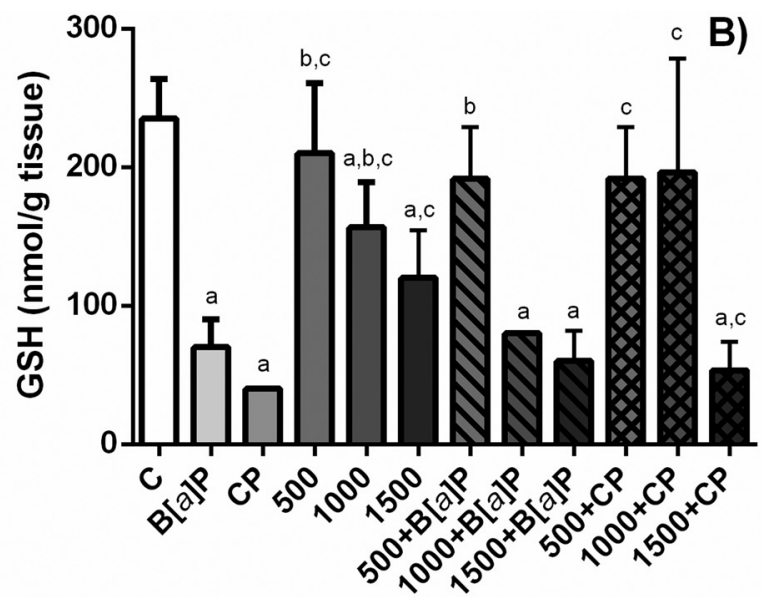

Treatments (mg/kg b. w.)

Figure 7 - Quantification of lipoperoxidation by measuring the formation of MDA, principal thiobarbituric acid-reactive specie (TBARS) (A) and GSH (B) in the kidney of mouse treated with $S$. dulcis bark ethanolic extract $(500,1000$, and $1500 \mathrm{mg} / \mathrm{kg}$ bw) associated or not to the positive controls (B $[\mathrm{a}] \mathrm{P}$ and $\mathrm{CP}$ ). Results are shown as means $\pm \mathrm{SD}$. ${ }^{\mathrm{a}}$ Statistically different from negative control group; ${ }^{\mathrm{b}}$ statistically different from $\mathrm{B}[\mathrm{a}] \mathrm{P}$ control group; ${ }^{\mathrm{c}}$ statistically different from CPA control group. MDA: malondialdehyde; GSH: glutathione; C: distilled water; B $[a] \mathrm{P}:$ benzo $[a]$ pyrene; CP: cyclophosphamide. Statistical analysis performed using ANOVA and Tukey's test with significance threshold of $p<0.05$.

aged nucleoids found in the comet assay. On the other hand, the extract of $S$. dulcis did not raise the number of damaged nucleoids, and it was able to prevent the DNA damage caused by $\mathrm{B}[a] \mathrm{P}$ and $\mathrm{CP}$. The extract of $S$. dulcis probably prevented DNA damage in the mouse cells due to the presence of flavonoids and phenolic acids in its composition. Other works have shown the effects of these polyphenols in the prevention of lesions on DNA that could result in carcinogenesis (Guo et al., 1996; Amararathna et al., 2016). The hydroxyl groups present in these polyphenols have the ability to donate hydrogen atoms, converting free radicals into chemically stable molecules, preventing DNA damage. These groups are also able to bond with biological membranes altering receptors and enzymes. Quercetin, a flavonoid found in the extract, has been pointed as a potent antagonist for the AhR and for the transcription factor involved in the activation of CYP enzymes (Denison et al., 2002, 2003; Murakami et al., 2008).

Permanent damage caused by adducts and strand breaks in DNA can be evaluated by the use of the micronucleus test. In bone marrow and in peripheral blood, the frequency of micronucleated cells was evaluated $24 \mathrm{~h}$ after the treatment. This time point was chosen based on the kinetics of micronucleus formation and cell migration (Vikram et al., 2007). From our work it is possible to conclude that the $S$. dulcis extract was not mutagenic, since after the treatment the experimental group showed the same number of micronucleated cells as the negative control group for both cell types. By using the micronucleus test it was also possible to assess the toxicity of the extract from the ratio $\mathrm{PCE} /(\mathrm{PCE}+\mathrm{NCE})$, since the appearance of polychromatic (PCE) or normochromatic erythrocytes (NCE) in bone marrow is an important indicator of cytotoxicity (Venkatesh et al., 2007). This ratio is important because it indi- cates the acceleration or inhibition of erythropoiesis, and a decline in this ratio suggests cytotoxicity of the test compound (Al-Harbi, 1993). Our results showed that none of the doses of the extract tested were cytotoxic, including in association with $\mathrm{B}[a] \mathrm{P}$ and $\mathrm{CP}$. In the antimutagenicity evaluation, as expected, $\mathrm{B}[a] \mathrm{P}$ and $\mathrm{CP}$ increased the number of micronuclei in bone marrow and peripheral blood after their administration, when compared to the negative control. However, the results show that the extract associated with $\mathrm{B}[a] \mathrm{P}$ and $\mathrm{CP}$ caused a significant reduction in the mean MNPCE and MNRET in the protocol used in this study.

Polyphenols also explain the enhancement of CAT activity in total blood and GSH levels in total blood, liver, and kidney after the treatment that associated $\mathrm{B}[a] \mathrm{P}$ and $\mathrm{CP}$ with the different doses of the extract. CAT is an enzyme ubiquitously found in cells, with the function to decompose hydrogen peroxide into water and oxygen (Majumder et al., 2017). The treatment with $\mathrm{B}[a] \mathrm{P}$ and $\mathrm{CP}$ reduced $\mathrm{CAT}$ activity, probably due to the release of hydrogen peroxide that led to the consumption of the enzyme. However, when the animals were treated with the extract of $S$. dulcis associated to the positive controls, CAT activity was restored to similar levels as those in the negative control. GSH $(\gamma$-L-glutamyl-L-cysteinylglycine) is one of the most important redox agents of aerobic organisms, as it serves as a ubiquitous nucleophile that converts a variety of electrophilic substances under physiological conditions. GSH mainly serves as a reducing agent for hydroperoxides (Deponte, 2013). The depletion of GSH levels after the treatment with $\mathrm{B}[a] \mathrm{P}$ and $\mathrm{CP}$, probably occurred because of the production of ROS, specially hydrogen peroxide, that led to GSH consumption. The ability of flavonoids to quench hydrogen peroxide was shown in previous studies (Bors et al., 1990; 
Pignatelli et al., 2000). Since flavonoids and phenolic acids are present in the $S$. dulcis extract, and they have the ability to quench hydrogen peroxide elicited by $\mathrm{B}[a] \mathrm{P}$ and $\mathrm{CP}$ metabolites, they probably acted synergistically, depleting the consumption of CAT in total blood and GSH in the erythrocytes, liver, and kidney cells.

TBARS have been employed to detect and quantify lipid peroxidation in a variety of chemical as well as biological matrices (Janero, 1990). The treatment with $\mathrm{B}[a] \mathrm{P}$ and $\mathrm{CP}$ enhanced the levels of MDA in liver and kidney, respectively, and the formation of ROS from $\mathrm{B}[a] \mathrm{P}$ and $\mathrm{CP}$ metabolites, specially hydrogen peroxide, probably enhanced lipid peroxidation in these organs. It is worthy of note that the treatment with $S$. dulcis extract did not raise significantly the levels of MDA in liver and kidney. The association of the extract with $\mathrm{B}[a] \mathrm{P}$ and $\mathrm{CP}$ depleted the levels of MDA significantly. Once again, polyphenols in the extract composition are probably the responsible agent for the depletion in MDA levels in liver and kidney. Other studies have shown that polyphenols can directly lower MDA levels in different organs (Dogan et al., 2013; Miao et al., 2014; Sen et al., 2015) and quercetin is able to suppress lipoperoxidation in the liver (Chowdhury and Giri, 2017).

From the results on protective effects of the $S$. dulcis extract it can be seen that the dose with the greatest effects was the lowest one $500 \mathrm{mg} / \mathrm{kg} \mathrm{bw}$ ). This is called an inverse dose-response, and it is very complex to analyze, since in a plant extracts several chemopreventive and antioxidant compounds can act synergistically (Knasmüller et al., 2002). Some of the phenolic compounds found in plant extracts can act as pro-oxidant under specific conditions (Dai and Mumper, 2010). In vivo conditions can also present divergent responses in different organs and cells, and other studies have also shown protective effects in an inverse dose-response manner, both in in vivo and in vitro conditions (Antunes and Takahashi, 1998; Ananthi et al., 2010; Tavares et al., 2011; Alves et al., 2013).

De Flora and Ferguson (2005) suggested that the antimutagenicity effects related to plant extracts could be due to: (i) inhibition of the DNA damage inducer uptake; (ii) binding to the DNA damage inducer inside or outside the cells, preventing its action on DNA; (iii) increasing levels of endogen antioxidant; and (iv) increasing the maintenance of DNA structure and modulation of DNA metabolism and repair. Based on the results found in this study, where polyphenols were found in the $S$. dulcis extract and both $\mathrm{B}[a] \mathrm{P}$ and $\mathrm{CP}$ induced DNA damage mainly by the induction of ROS production, we propose that $S$. dulcis bark ethanolic extract acted by increasing the levels of endogen antioxidant(s) in the mouse cells, contributing with the antimutagenic effect seen for $S$. dulcis extract.

In conclusion, we have shown for the first time that the Spondias dulcis bark ethanolic extract does not show cytotoxic, genotoxic, or mutagenic activity in bone marrow and peripheral blood of mice. This extract presented protective effects against $\mathrm{B}[a] \mathrm{P}$ - and $\mathrm{CP}$-induced DNA damage, depleting the number of damaged nucleoids, MNPCE, and MNRET in these animals. This extract also increased CAT activity in blood and GSH levels in blood, liver, and kidney, and depleted MDA levels in liver and kidney of animals treated with $\mathrm{B}[a] \mathrm{P}$ and $\mathrm{CP}$. The results obtained in this study indicate that the Spondias dulcis extract could be useful as preventive compound against DNA damage caused by mutagenic agents $\mathrm{CP}$ and $\mathrm{B}[a] \mathrm{P}$. More studies are being conducted in order to clarify and isolate the compounds of the Spondias dulcis extract and to elucidate their properties.

\section{Acknowledgments}

The authors greatfully acknowledge Coordenação de Aperfeiçoamento de Pessoal de Ensino Superior (CAPES/DS) - Finance Code 001, Fundação de Amparo à Pesquisa do Estado de São Paulo (FAPESP), Universidade Estadual Paulista "Júlio de Mesquita Filho" and Universidade do Oeste Paulista (UNOESTE) for the financial support received, and Agência Paulista de Tecnologia dos Agronegócios (APTA) for the use of its facilities.

\section{Conflict of interest}

The authors declare that there are no conflict of interest.

\section{Author contributions}

CSA, LDB, MOT, NJFS, KSR and ASG conducted the experiments. DGSM, MAZ, EY, MLC, AEJ and LEK wrote the manuscript. LEK conceived and designed the study. All authors read and approved the final version.

\section{References}

Abo-Zeid MAM, Abdel-Samie NS, Farghaly AA and Hassan EM (2018) Flavonoid fraction of Cajanus cajan prohibited the mutagenic properties of cyclophosphamide in mice in vivo. Mutat Res Gen Tox En 826:1-5.

Aebi H (1984) Catalase in vitro. Methods Enzymol 105:121-126.

Al-Harbi MM (1993) Effect of captopril on the cytological and biochemical changes induced by Adriamycin. Food Chem Toxicol 31:209-212.

Alves JM, Munari CC, de Azevedo Bentes Monteiro Neto M, Furtado RA, Senedese JM, Bastos JK and Tavares DC (2013) In vivo protective effect of Copaifera langsdorffii hydroalcoholic extract on micronuclei induction by doxorubicin. J Appl Toxicol 33:854-860.

Amararathna M, Johnston MR and Rupasinghe HPV (2016) Plant polyphenols as chemopreventive agents for lung cancer. Int J Mol Sci 17:1352-1365.

Amic D, Davidovic-Amic D, Belo D, Rastija V, Lucic B and Trinajstic N (2007) SAR and QSAR of the antioxidant activity of flavonoids. Curr Med Chem 14:827-845.

Ananthi R, Chandra N and Santhiya ST (2010) Protective effect of Hemidesmus indicus $\mathrm{R}$. Br. root extract against cisplatininduced cytogenetic damage in mouse bone marrow cells. Genet Mol Biol 33:182-185. 
Antunes LM and Takahashi CS (1998) Effects of high doses of vitamins $\mathrm{C}$ and $\mathrm{E}$ against doxorubicin-induced chromosomal damage in Wistar rat bone marrow cells. Mutat Res 419:1-3.

Biasi F, Astegiano M, Maina M, Leonarduzzi G and Poli G (2011) Polyphenols supplementation as a complementary medicinal approach to treating inflammatory bowel disease. Curr Med Chem 18:4851-4865.

Bors W, Heller W, Michel C and Saran M (1990) Flavonoids as antioxidants: Determination of radical-scavenging efficiencies. Methods Enzymol 186:343-367.

Chowdhury P and Giri A (2017) A study of correlation between anti-peroxidative potential of quercetin and ascorbic acid with malondialdehyde by RP-HPLC. Curr Chem Biol 11:21-27.

Christmann M, Boisseau C, Kitzinger R, Berac C, Allmann S, Sommer T, Aasland D, Kaina B and Tomicic MT (2016) Adaptative upregulation of DNA repair genes following benzo[a]pyrene diol epoxide protects against cell death at the expenses of mutations. Nucleic Acids Res 44:1072710743.

Cuyacot AR, Mahilum JJM and Madamba MSB (2014) Cytotoxicity potentials of some medicinal plants in Mindanao, Philippines. Asian J Plant Sci Res 4:81-89.

Dai J and Mumper RJ (2010) Plant phenolics: Extraction, analysis and their antioxidant and anticancer properties. Molecules 15:7313-7352.

De Flora S and Ferguson LR (2005) Overview of mechanisms of cancer chemopreventive agents. Mutat Res 591:8-15.

Denison MS, Pandini A, Nagy SR, Baldwin EP and Bonati L (2002) Ligand binding and activation of the Ah receptor. Chem Biol Interact 141:3-24.

Denison MS and Nagy SR (2003) Activation of the arylhydrocarbon receptor by structurally diverse exogenous and endogenous chemicals. Annu Rev Pharmacol Toxicol 43:309-334

Denissenko MF, Pao A, Tang M and Pfeifer GP (1996) Preferential formation of benzo[a]pyrene adducts at lung cancer mutational hotspots in P53. Science 274:430-432.

Deponte M (2013) Glutathione catalysis and the reaction mechanisms of glutathione-dependent enzymes. Biochim Biophys Acta 1830:3217-3266.

Dogan F, Armagan A, Oksay T, Akman T, Aylak F and Bas E (2013) Impact of micronized purified flavonoid fraction on increased malondialdehyde and decreased metalloproteinase-2 and metalloproteinase-9 levels in varicocele: outcome of an experimentally induced varicocele. Int J Androl 46:380-385

Drimal J, Zurova-Nedelcevova J, Knezl V, Sotnikova R and Navarova J (2006) Cardiovascular toxicity of the first line cancer chemotherapeutic agents: doxorubicin, cyclophosphamide, streptozotocin and bevacizumab. Neuroendocrinol Lett 27:176-179.

Ellman GL (1959) Tissue sulfhydryl groups. Arch Biochem Biophys 82:70-77.

Ettawa A, Dhibi S, Samout N, Elfeki A and Hfaiedh N (2016) Hepatoprotective activity of white horehound (Marrubium vulgare) extract against cyclophosphamide toxicity in male rats. Can J Physiol Pharmacol 94:441-447.

Ferreira-Machado SC, Gagliardi RF, Nunes APM, Rodriges MP, Dantas FJS, De Mattos JCP, Peregrino CAF, Moura EG and Caldeira-de-Araujo A (2014) Antidiabetic and genotoxic effects on Wistar rats treated with aqueous extract from Chrysobalanus icaco L. J Med Plants Res 8:52-57.
Gunes S, Sahinturk V, Karasati P, Sahin IK and Ayhanci A (2017) Cardioprotective effect of selenium against cyclophosphamide-induced cardiotoxicity in rats. Biol Trace Elem Res 177:107-114.

Guo Q, Zhao B, Li M, Shen S and Xin W (1996) Studies on protective mechanisms of four components of green tea polyphenols against lipid peroxidation in synaptosomes. Biochim Biophys Acta-Lipids Lipid Metab 1304:210-222.

Hayashi M, Morita T, Kodama Y, Sofuni T and Ishidate Jr M (1990) The micronucleus assay with mouse peripheral blood reticulocytes using acridine orange-coated slides. Mutat Res 245:245-249.

Hollman PC, van Trijp JM, Buysman MN, van der Gaag MS, Mengelers MJ, de Vries JH and Katan MB (1997) Relative bioavailability of the antioxidant flavonoid quercetin from various foods in man. FEBS Lett 418:152-156.

Huang Z, Huang Q, Ji L, Wang Y, Qi X, Liu L, Liu Z and Lu L (2016) Epigenetic regulation of active Chinese herbal components for cancer prevention and treatment: A follow-up review. Pharmacol Res 114:1-12.

Huda-Faujan N, Noriham A, Norrakiah AS and Babji AS (2009) Antioxidant activity of plants methanolic extracts containing phenolic compounds. Afr J Biotechnol 8:484-489.

IARC Working Group on the Evaluation of Carcinogenic Risks to Humans and International Agency for Research on Cancer (2010) Some non-heterocyclic polycyclic aromatic hydrocarbons and some related occupational exposures. IARC Press, Lyon.

Ince M, Kaplan IO and Yaman M (2017) Food optimization of an analytical method for determination of pyrene in smoked meat products. Anal Methods 10:2060.

Janero DR (1990) Malondialdehyde and thiobarbituric acid-reactivity as diagnostic indices of lipid peroxidation and peroxidative tissue injury. Free Radic Biol Med 9:515-540.

Jantan N (2010) In vitro antidiabetic of Cemumar (Micromelum pubescens), Tebengau (Ehretia laevis) and Kedondong (Spondias dulcis) leaves extract. Universiti Malaysia Perlis, Perlis.

Kaur C and Kapoor HC (2002) Anti-oxidant activity and total phenolic content of some Asian vegetables. Int J Food Sci Technol 37:153-161.

Knasmüller S, Steinkellner H, Majer BJ, Nobis EC, Scharf G and Kassie F (2002) Search for dietary antimutagens and anticarcinogens: methodological aspects and extrapolation problems. Food Chem Toxicol 40:1051-1062.

Lather A, Valecha R, Sharma K and Garg M (2011) Worldwide potential of plants causing teratogenicity: An overview. Spatula DD 1:101-106.

Majumder D, Das A and Saha C (2017) Catalase inhibition an anticancer property of flavonoids: A kinetic and structural evaluation. Int J Biol Macromol 104:929-935.

Manoharan K and Banerjee MR (1985) B-carotene reduces sister chromatid exchange induce chemical carcinogens in mouse mammary cells in organ culture. Cell Biol Int Rep 9:783789.

Miao G, Zhao H, Guo K, Cheng J, Zhang S, Zhang X, Cai Z, Miao $\mathrm{H}$ and Shang Y (2014) Mechanisms underlying attenuation of apoptosis of cortical neurons in the hypoxic brain by flavonoids from the stems and leaves of Scutellaria baicalensis Georgi. Neural Regen Res 9:1592-1598.

Mocanu MM, Nagy P and Szollosi J (2015) Chemoprevention of breast cancer by dietary polyphenols. Molecules 20:2257822620. 
Morton JF (1987) Fruits of warm climates. Florida Flair Books, Miami, pp 240-242.

Murakami A, Ashida H and Terao J (2008) Multitargeted cancer prevention by quercetin. Cancer Lett 269:315-325.

Narain N, Almeida JN, Galvão MS, Madruga MS and Brito ES (2004) Compostos voláteis dos frutos de maracujá (Passiflora edulis forma flavicarpa) e de cajá (Spondias mombin L.) obtidos pela técnica de Headspace dinâmico. Ciência Tec Alimentos 24:212-216.

Olfert ED, Cross BM and McWilliam AA (1993) Guide to the Care and Use of Experimental Animals. $2^{\text {nd }}$ edn. Canadian Council on Animal Care, Ottawa.

Partap S, Kumar A, Sharma NK and Jha KK (2012) Luffa cylindrical: An important medicinal plant. J Nat Prod Plant Resour 2:127-134.

Perini P, Calabrese M, Rinaldi L and Gallo P (2007) The safety profile of cyclophosphamide in multiple sclerosis therapy. Expert Opin Drug Saf 6:183-190.

Pignatelli P, Pulcinelli FM, Celestini A, Lenti L, Ghiselli A, Gazzaniga PP and Violi F (2000) The flavonoids quercetin and catechin synergistically inhibit platelet function by antagonizing the intracellular production of hydrogen peroxide. Am J Clin Nutr 72:1150-1155.

Rahmatullah M, Ferdausi D, Mollik MA, Azam MN, Rahman MT and Jahan R (2009) Ethnomedical survey of bheramara area in Kushtia district, Bangladesh. Am-Euras J Sustain Agric 3:534-541.

Rice-Evans CA, Miller NJ and Paganga G (1996) Structureantioxidant activity relationships of flavonoids and phenolic acids. Free Rad Biol Med 20:933-956.

Rolim A, Maciel COM, Kaneko TM, Consiglieri VO, SalgadoSantos IMN and Velasco MVR (2005) Validation assay for total flavonoids, as rutin equivalents, from Trichiliacatigua Adr. Juss. (Meliaceae) and Ptychopeta lumolacoides Bentham (Olacaceae) commercial extract. J AOAC Int 88:1015-1019.

Sarker MM, Nimmi I and Kawsar MH (2012) Preliminary screening of six popular fruits of Bangladesh for in vitro IgM production and proliferation of splenocytes. Bangladesh Pharm J 15:31-37.

Schmid W (1975) The micronucleus test. Mutat Res 31:9-15.

Sedlak J and Lindsay RH (1968) Estimation of total, proteinbound, and nonprotein sulfhydryl groups in tissue with Ellman's reagent. Anal Biochem 25:192-205.

Sen HM, Ozkan A, Guven M, Akman T, Aras AB, Sehitoglu I, Alacam H, Silan C, Cosar M and Ozisik Karaman HI (2015) Effects of tannic acid on the ischemic brain tissue of rats. Inflammation 38:1624-1630.

Shi Q, Godschalk RWL and van Schooten FJ (2017) Inflammation and the chemical carcinogen benzo[a]pyrene: Partners in crime. Mutat Res Rev Mutat 774:12-24.

Singh NP, McCoy MT, Tice RR and Schneider EL (1988) A simple technique for quantitation of low levels of DNA damage in individuals cells. Exp Cell Res 175:184-191.

Sloczynska K, Powroznik B, Pekala E and Waszkielewicz AM (2014) Antimutagenic compounds and their possible mechanisms of action. J Appl Genetics 55:273-285.

Song J, Liu L, Li L, Liu J, Song E and Song Y (2014) Protective effects of lipoic acid and mesna on cyclophosphamide in- duced haemorrhagic cystitis in mice. Cell Biochem Funct 32:125-132.

Speit G and Hartmann A (2005) The comet assay: A sensitive genotoxicity test for the detection of DNA damage. Methods Mol Biol 291:85-95.

Szkudelski T and Szkudelska K (2015) Resveratrol and diabetes: From animals to human studies. Biochim Biophys Acta 1852:1145-1154.

Tavares DC, Munari CC, Araújo MG, Beltrame MC, Furtado MA, Gonçalves CC, Tiossi RF, Bastos JK, Cunha WR and Veneziani RC (2011) Antimutagenic potential of Solanum lypocarpum against induction of chromosomal aberrations in V79 cells and micronuclei in mice by doxorubicin. Planta Med 77:1489-1494.

Tice RR, Agurell E, Anderson D, Burlinson B, Hartmann A, Kobayashi H, Miyamae Y, Rojas E, Ryu JC and Sasaki YF (2000) Single cell gel/comet assay: guidelines for in vitro and in vivo genetic toxicology testing. Environ Mol Mutagen 25:206-221.

Uchiyama M and Mihara M (1978) Determination of malonaldehyde precursor in tissues by thiobarbituric acid test. Anal Biochem 86:271-278.

Venkatesh P, Shantala B, Jagetia GC, Rao KK and Baliga MS (2007) Modulation of doxorubicin-induced genotoxicity by Aegle marmelos in mouse bone marrow: A micronucleus study. Integr Cancer Ther 6:42-53.

Vikram A, Ramarao P and Jena G (2007) Prior bleeding enhances the sensitivity of peripheral blood and bone marrow micronucleus tests in rats. Mutagenesis 22:287-291.

Wagner H and Bladt S (2001) Plant Drug Analysis: A thin layer chromatography Atlas. $2^{\text {nd }}$ ed. Springer, Berlin.

Waters MD, Brady AL, Stack HF and Brockman HE (1990) Antimutagenicity profiles for some model compounds. Mutat Res 238:57-85.

Wiart C (2006) Medicinal plants of Asia and the Pacific. CRC Press, New York, p. 179.

Wilms LC, Hollman PCH, Boots AW and Kleinjans JCS (2005) Protection by quercetin-rich fruit juice against induction of oxidative DNA damage and formation of BPDE-DNA adducts in human lymphocytes. Mutat Res Gen Tox Environ 582:155-162.

Yamagata K, Tagami M and Yamori Y (2015) Dietary polyphenols regulate endothelial function and prevent cardiovascular disease. Nutrition 31:28-37.

Yao C, Foster WG, Sadeu JC, Siddique S, Zhu J and Feng YL (2017) Screening for DNA adducts in ovarian follicles exposed to benzo[a]pyrene and cigarette smoke condensate using liquid chromatography-tandem mass spectrometry. Sci Total Environ. 575:742-749.

Zhang J, Tian Q, Chan SY, Li SC, Zhou S, Duan W and Zhu YZ (2005) Metabolism and transport of oxazaphosphorines and the clinical implications. Drug Metab Rev 37:611-703.

\section{Associate Editor: Daisy Maria Fávero Salvadori}

License information: This is an open-access article distributed under the terms of the Creative Commons Attribution License (type CC-BY), which permits unrestricted use, distribution and reproduction in any medium, provided the original article is properly cited. 